\title{
EFFECT OF LOW LEVELS OF GARBON DIOXIDE ON THE METABOLISM OF RAM AND BULL SPERMATOZOA
}

\author{
R. G. WALES AND T. O'SHEA \\ Department of Veterinary Physiology, University of Sydney, \\ Sydney, Australia
}

(Received 23rd March 1965, accepted 27th September 1965)

\begin{abstract}
Summary. The metabolism of semen in the presence and in the absence of carbon dioxide was examined using isotopically labelled substrates. When carbon dioxide was present, both oxygen consumption and carbon dioxide formation were determined in the one manometric flask. Respired carbon dioxide had no effect on oxygen uptake, substrate oxidation or aerobic fructolysis of ram spermatozoa. The addition of low levels of potassium and magnesium ions to the diluent stimulated the metabolism of washed ram spermatozoa, but there was still no effect of carbon dioxide on aerobic metabolism. Incubation of ram spermatozoa in an atmosphere containing $3.8 \%$ carbon dioxide increased the amount of lactate accumulated but had no effect on oxygen uptake or substrate oxidation. The necessity to distinguish between the effects of $\mathrm{pH}$ and carbon dioxide has been shown. In the presence of added fructose, the respiratory quotient of ram spermatozoa was approximately unity but was 0.78 for washed semen incubated in phosphate-buffered saline without added substrate.

The presence of respired carbon dioxide during incubation of bull spermatozoa had no effect on oxygen uptake or substrate oxidation but increased lactate accumulation. With fructose as substrate, incubation of bull spermatozoa in phosphate-buffered saline and saline gave respiratory quotients of 0.97 and 0.83 respectively.
\end{abstract}

\section{INTRODUCTION}

Investigations of the metabolism of spermatozoa are usually carried out in the presence of a strong alkali to absorb respired carbon dioxide and enable the oxygen uptake to be measured. The finding that high levels of carbon dioxide are inhibitory to sperm metabolism (Salisbury \& VanDemark, 1957) did not affect the rationale of this method, but recent reports that respired carbon dioxide stimulates the metabolism of bull semen (Salisbury \& Kinney, 1957; Salisbury \& Lodge, 1963; Lodge \& Salisbury, 1963) throw doubt on the possible physiological significance of many of the previous studies of sperm metabolism. Because of this, the effects of both respired and added carbon dioxide on the respiration of ram spermatozoa has been investigated. Some experiments were also carried out with bull spermatozoa. 


\section{MATERIALS AND METHODS}

\section{Semen and diluents}

Ram semen was collected by means of electrical stimulation (Blackshaw, 1954) and bull semen with an artificial vagina. Only apparently normal ejaculates with good initial motility were used. The basic diluent consisted of $20 \mathrm{~mm}$-mono- and di-sodium phosphate buffer ( $\mathrm{pH} 7 \cdot 0$ ), 127 mM-sodium chloride, $30 \mathrm{mg} \%$ penicillin and $50 \mathrm{mg} \%$ streptomycin. Unless otherwise stated, washed spermatozoa suspensions were obtained by diluting the semen with 5 vol. of basic diluent and centrifuging at $400 \mathrm{~g}$ for $7 \mathrm{~min}$. The supernatant was replaced with an equal volume of diluent and the spermatozoa were dispersed and recentrifuged. After removing the second supernatant, the spermatozoa were diluted to the required volume.

For most incubations, fructose (6 to $10 \mathrm{~mm}$ ) and L-sodium lactate (3 to 6 $\mathrm{mM}$ ) were included in the incubation diluent and isotonicity was maintained by decreasing the sodium chloride content to compensate for the added substrate. In order to measure both fructose and lactate oxidation in an experiment, duplicate Warburg flasks were prepared for each treatment. To one was added $\mathrm{D}-\mathrm{U}-{ }^{14} \mathrm{C}$ fructose and to the other $\mathrm{DL}-1-{ }^{14} \mathrm{C}$ lactate as carrier free isotopes in $0.1 \mathrm{ml}$ of isotonic saline. All isotopes were obtained from the Radiochemical Centre, Amersham. By assay of the trapped carbon dioxide in each flask, the amount of each substrate oxidized could be assessed from the ${ }^{14} \mathrm{CO}_{2}$ recovered.

\section{Incubation of spermatozoa}

The experiments were carried out at $37^{\circ} \mathrm{C}$ in double-side-arm Warburg flasks of 16 to $24 \mathrm{ml}$ capacity. The side arms were stoppered with rubber caps (subaseal caps No. 9) through which injections could be made into the flasks during the incubations. During incubation, all flasks contained $3 \mathrm{ml}$ of appropriately diluted semen suspension, and, at the completion of all incubations, the spermatozoa were inactivated by adding $0.1 \mathrm{ml}$ of $6 \mathrm{~N}-\mathrm{H}_{2} \mathrm{SO}_{4}$ from one side-arm.

In the experiments to study the effect of respired carbon dioxide, flasks were incubated either without alkali $\left(+\mathrm{CO}_{2}\right)$ or in the presence of $20 \% \mathrm{KOH}$ to absorb respired carbon dioxide $\left(-\mathrm{CO}_{2}\right)$. Where the effect of $100 \%$ oxygen or $3.8 \%$ carbon dioxide was examined, the flask was flushed during the equilibration period, the gas entering through the stop-cock of the manometer and escaping through No. 19 gauge hypodermic needles inserted through the side-arm caps. In order to keep strict comparison of conditions in these experiments, controls were flushed with air during equilibration. The carbon dioxide-gas mixture consisted of $3.8 \%$ carbon dioxide, $16 \%$ oxygen and $80.2 \%$ nitrogen.

For all incubations in the presence of carbon dioxide, initial flasks were prepared to measure initial levels of the gas. Immediately after equilibration, the reaction in the initial flasks was terminated by adding excess acid from one side arm. When manometric readings were constant, an exact amount of $20 \% \mathrm{KOH}$ was injected into the other side arm, and, from the readings before 
and after alkali injection, corrected for the volume of injected alkali, both initial bound carbon dioxide and carbon dioxide in the gas phase could be calculated. The incubated flasks were treated at the completion of incubation in a similar fashion to the initial flasks, and, after correction for initial carbon dioxide levels, both oxygen consumption and carbon dioxide production were calculated.

\section{Analytical and statistical methods}

The methods used for the preparation of protein free extracts, for the estimation of fructose, lactate and sorbitol and for the assay of radioactivity after precipitation as $\mathrm{Ba}^{14} \mathrm{CO}_{3}$ have been described elsewhere (O'Shea \& Wales, 1965). Substrate oxidation was calculated from the radioactivity of the trapped carbon dioxide and the specific activity of the substrates at the beginning of incubation. For each experiment, spermatozoa concentration was estimated by direct counts in a haemocytometer and all results are expressed as $\mu$ moles per $10^{8}$ spermatozoa over the experimental period. Fructose utilization, or fructolysis, and lactate accumulation were measured by difference between final and initial levels in the suspensions. Of the fructose utilized, only a small proportion was oxidized to carbon dioxide.

All experiments were of factorial design and the significance of results has been assessed by the analysis of variance. Where duplicate samples were tested, the variance between duplicates was used as error except where the ejaculate interactions were significantly larger. In all other experiments, pooled ejaculate interactions were used as error. Where presented, the analyses are given in summary form giving only degrees of freedom (d.f.) and variance ratios for each source of variation. The error variance is given in italics at the base of the variance ratio column. In the other Tables, the standard errors of the printed means $\left(\right.$ S.E. $_{{ }_{\mathrm{m}}}$ ) calculated from the error variance of the statistical analyses are given with the associated degrees of freedom in parenthesis.

\section{RESULTS}

The effect of respired carbon dioxide on the metabolism of washed and unwashed ram spermatozoa ( 6.5 to $11 \times 10^{8}$ cells/flask) was investigated by incubating suspensions in basic diluent containing fructose and lactate as substrate. The mean results for four replicates, together with the summaries of the analyses of variance, are given in Table 1. During the incubation the carbon dioxide content of the flask rose to approximately $2 \%(\mathrm{v} / \mathrm{v})$. There was no significant effect of respired carbon dioxide on either respiration or aerobic fructolysis of washed or unwashed spermatozoa when compared with similar suspensions incubated in the presence of alkali. Washing caused a significant increase in oxygen uptake and lactate oxidation, but decreased fructolysis. Washed suspensions also had a slightly higher respiratory quotient than unwashed cells.

The following tests were carried out to investigate if the composition of diluents affected the reaction of spermatozoa to respired carbon dioxide. In the first 
experiment, the effect of phosphate buffer was examined by comparing metabolism in the basic diluent containing fructose and lactate with that in an isotonic diluent composed of sodium chloride, antibacterials and substrates only. The results and summaries of the analyses of variance for three ejaculates of unwashed ram semen (2.5 to $4 \times 10^{8}$ spermatozoa/flask) are shown in Table 2 . The presence of phosphate greatly increased aerobic fructolysis and respiration and caused a slight fall in the respiratory quotient. Carbon dioxide, on the other hand, had no effect on metabolism either in the presence or absence of phosphate.

TABLE 1

METABOLISM OF WASHED AND UNWASHED RAM SPERMATOZOA IN THE PRESENGE AND IN THE ABSENGE OF RESPIRED $\mathrm{CO}_{2}$

\begin{tabular}{c|c|c|c|c|c|c|c|c}
\hline \multirow{2}{*}{ Treatment } & $\begin{array}{c}\text { Gas } \\
\text { phase }\end{array}$ & $\begin{array}{c}\mathrm{O}_{2} \\
\text { uptake }\end{array}$ & $\begin{array}{c}\text { Fructose } \\
\text { oxidized }\end{array}$ & $\begin{array}{c}\text { Lactate } \\
\text { oxidized }\end{array}$ & $\begin{array}{c}\text { Fructose } \\
\text { utilized }\end{array}$ & $\begin{array}{c}\text { Lactate } \\
\text { accumulated }\end{array}$ & $\begin{array}{c}\text { Sorbitol } \\
\text { accumulated }\end{array}$ & R.Q. \\
\hline Unwashed & $-\mathrm{CO}_{2}$ & 1.49 & 0.047 & 0.430 & 0.65 & 1.18 & 0.08 & - \\
\multirow{3}{*}{ Washed } & $+\mathrm{CO}_{2}$ & 1.47 & 0.052 & 0.407 & 0.80 & 1.20 & 0.10 & 0.99 \\
& $-\mathrm{CO}_{2}$ & 1.72 & 0.056 & 0.523 & 0.50 & 0.83 & 0.11 & - \\
& $+\mathrm{CO}_{2}$ & 1.70 & 0.056 & 0.505 & 0.43 & 0.66 & 0.10 & 1.03 \\
\hline
\end{tabular}

All values are expressed as $\mu$ mole $/ 10^{8}$ spermatozoa over the experimental period $\left(1 \frac{1}{2} \mathrm{hr}\right)$ and are the means for four ejaculates.

SUMMARY OF THE ANALYSES OF VARIANCE

\begin{tabular}{|c|c|c|c|c|c|c|c|c|}
\hline \multirow{2}{*}{$\begin{array}{l}\text { Source of } \\
\text { variation }\end{array}$} & \multirow[b]{2}{*}{ d.f. } & \multicolumn{7}{|c|}{ Variance ratios } \\
\hline & & $\begin{array}{c}\mathrm{O}_{2} \\
\text { uptake }\end{array}$ & $\begin{array}{l}\text { Fructose } \\
\text { oxidized }\end{array}$ & $\begin{array}{c}\text { Lactate } \\
\text { oxidized }\end{array}$ & $\begin{array}{l}\text { Fructose } \\
\text { utilized }\end{array}$ & $\begin{array}{c}\text { Lactate } \\
\text { accumulated }\end{array}$ & $\begin{array}{c}\text { Sorbitol } \\
\text { accumulated }\end{array}$ & $R . Q$. \\
\hline $\begin{array}{l}\text { A. Effect of } \mathrm{CO}_{2} \\
\text { B. Effect of washing }\end{array}$ & 1 & $\begin{array}{l}0 \cdot 05 \\
9 \cdot 97 *\end{array}$ & $\begin{array}{l}0 \cdot 40 \\
2 \cdot 33\end{array}$ & $\begin{array}{l}2 \cdot 07 \\
45 \cdot 48^{* *}\end{array}$ & $\begin{array}{l}0 \cdot 19 \\
8 \cdot 94^{* *}\end{array}$ & $\begin{array}{c}0 \cdot 00 \\
14 \cdot 12 * *\end{array}$ & $\begin{array}{l}0 \cdot 28 \\
0 \cdot 85\end{array}$ & 8.98* \\
\hline $\mathrm{A} \times \mathrm{B}$ & 1 & 0.001 & $0 \cdot 26$ & 0.03 & $1 \cdot 48$ & $0 \cdot 30$ & $0 \cdot 46$ & - \\
\hline $\begin{array}{l}\text { Ejaculate } \\
\text { differences } \\
\text { Ejaculate } \\
\text { interactions }\end{array}$ & $\begin{array}{l}3 \\
9\end{array}$ & $\begin{array}{l}3 \cdot 74 * \\
0.0420\end{array}$ & $\begin{array}{l}3.57 \\
0.00007\end{array}$ & $\begin{array}{r}15.08^{* *} \\
0.0005\end{array}$ & $\begin{array}{l}3.31^{*} \\
1.07\end{array}$ & $\begin{array}{l}1.86 \\
1.86\end{array}$ & $\begin{array}{l}2.05 \\
0.0030\end{array}$ & $\begin{array}{l}17 \cdot 85^{* *} \\
\text { (3) } 1.01\end{array}$ \\
\hline $\begin{array}{l}\text { Within group } \\
\text { variance }\end{array}$ & 16 & 0.0028 & - & - & 0.0006 & 0.0009 & 0.0007 & (8) 0.0007 \\
\hline
\end{tabular}

The above experiment was repeated with three ejaculates of bull semen ( 2 to $4 \times 10^{8}$ spermatozoa/flask). The results (Table 3 ) showed a significant increase in lactate accumulation and a decrease in respiratory quotient in the presence of phosphate. There was no effect of phosphate on oxygen uptake or substrate oxidation. The only effect of carbon dioxide was to increase lactate accumulation. This occurred both in the presence and in the absence of phosphate ions.

To determine if changes in spermatozoa concentration, or more severe washing, or the presence of potassium (1 $\mathrm{mm}$ ) plus magnesium ( $2 \mathrm{mM})$ in the 
diluent would cause respired carbon dioxide to affect aerobic metabolism of ram spermatozoa, ejaculates were washed twice in 10 vols. of basic diluent and incubated at two cell concentrations (means : 2.0 and $6.0 \times 10^{8}$ spermatozoa/flask) with fructose $(6 \mathrm{~mm})$ as substrate. The results are given in Table 4. The addition of potassium and magnesium to the diluent stimulated both respiration and aerobic fructolysis. There was a slight dilution effect and the more concentrated suspensions had the higher oxygen uptake. However, there was no effect of respired carbon dioxide either in the presence of potassium plus magnesium or at either cell concentration used.

TABLE 2

EFFECT OF RESPIRED $\mathrm{CO}_{2}$ ON THE METABOLISM OF UNWASHED RAM SPERMATOZOA IN THE PRESENCE AND IN THE ABSENCE OF PHOSPHATE BUFFER

\begin{tabular}{c|c|c|c|c|c|c|c}
\hline \multirow{2}{*}{ Phosphate } & $\begin{array}{c}\text { Gas } \\
\text { phase }\end{array}$ & $\begin{array}{c}\mathrm{O}_{2} \\
\text { uptake }\end{array}$ & $\begin{array}{c}\text { Fructose } \\
\text { oxidized }\end{array}$ & $\begin{array}{c}\text { Lactate } \\
\text { oxidized }\end{array}$ & $\begin{array}{c}\text { Fruttose } \\
\text { utilized }\end{array}$ & $\begin{array}{c}\text { Lactate } \\
\text { accumulated }\end{array}$ & R.Q. \\
\hline \multirow{2}{*}{+} & $-\mathrm{CO}_{2}$ & 3.04 & 0.054 & 0.686 & 0.83 & 0.88 & - \\
+ & $+\mathrm{CO}_{2}$ & 3.20 & 0.047 & 0.679 & 1.02 & 0.63 & 1.03 \\
+ & $-\mathrm{CO}_{2}$ & 4.23 & 0.116 & 0.844 & 2.30 & 3.09 & $-\overline{.}$ \\
& $+\mathrm{CO}_{2}$ & 4.41 & 0.144 & 0.874 & 2.41 & 3.12 & 0.98 \\
\hline
\end{tabular}

All values are expressed as $\mu$ mole $/ 10^{8}$ spermatozoa over the experimental period $(3 \mathrm{hr})$ and are the means for three ejaculates.

SUMMARY OF THE ANALYSES OF VARIANGE

\begin{tabular}{|c|c|c|c|c|c|c|c|}
\hline \multirow{2}{*}{$\begin{array}{l}\text { Source of } \\
\text { variation }\end{array}$} & \multirow[b]{2}{*}{ d.f. } & \multicolumn{6}{|c|}{ Variance ratios } \\
\hline & & $\begin{array}{c}\mathrm{O}_{2} \\
\text { uptake }\end{array}$ & $\begin{array}{l}\text { Fructose } \\
\text { oxidized }\end{array}$ & $\begin{array}{c}\text { Lactate } \\
\text { oxidized }\end{array}$ & $\begin{array}{l}\text { Fructose } \\
\text { utilized }\end{array}$ & $\begin{array}{c}\text { Lactate } \\
\text { accumulated }\end{array}$ & R.Q. \\
\hline $\begin{array}{l}\text { A. Effect of phosphate } \\
\text { B. Effect of } \mathrm{CO}_{2}\end{array}$ & $\begin{array}{l}1 \\
1\end{array}$ & $\begin{array}{l}27 \cdot 86^{* *} \\
0.57\end{array}$ & $\begin{array}{l}20 \cdot 98^{* *} \\
0 \cdot 38\end{array}$ & $\begin{array}{l}82 \cdot 84^{* * *} \\
0.33\end{array}$ & $\begin{array}{c}183 \cdot 86^{* *} \\
2 \cdot 16\end{array}$ & $\begin{array}{c}220 \cdot 45^{* * *} \\
0.48\end{array}$ & $\begin{array}{l}7 \cdot 51^{*} \\
-\end{array}$ \\
\hline $\mathrm{A} \times \mathrm{B}$ & 1 & 0.00 & 1.00 & 0.92 & $0 \cdot 14$ & 0.71 & - \\
\hline $\begin{array}{l}\text { Ejaculate differences } \\
\text { Ejaculate interactions }\end{array}$ & $\begin{array}{l}2 \\
6\end{array}$ & $\begin{array}{l}1.61 \\
0.3111\end{array}$ & $\begin{array}{l}6.94^{*} \\
0.0009\end{array}$ & $\begin{array}{c}37 \cdot 77^{* *} \\
0.0011 \dagger\end{array}$ & $\begin{array}{l}7 \cdot 64 * * \\
2 \cdot 84\end{array}$ & $\begin{array}{l}5 \cdot 89 * \\
2 \cdot 14\end{array}$ & (2) $\begin{array}{l}0.23 \\
0.50\end{array}$ \\
\hline Within group variance & 12 & 0.0280 & - & - & 0.0666 & 0.1501 & (6) 0.0008 \\
\hline
\end{tabular}

* $P<0.05 ; \quad$ ** $P<0.01$.

$\dagger$ d.f. reduced by 1 to correct for missing value.

The effect of respired carbon dioxide on the metabolism of washed ram spermatozoa incubated in diluents without added substrate was also examined. Four ejaculates of ram spermatozoa were twice washed in 10 vols. of basic diluent and incubated $3 \mathrm{hr}$ in phosphate buffered saline with and without the addition of potassium (1 $\mathrm{mm}$ ) and magnesium $(2 \mathrm{~mm})$ ions. After washing, analyses failed to detect fructose or lactate in the suspension. Neither the respired carbon dioxide nor the added ions had a significant effect on oxygen uptake. The mean respiratory quotient for the four ejaculates was 0.78 (S.E. $=$ 0.02 ) and was not affected by the addition of potassium and magnesium to the diluent. 
Using the basic incubation diluent, the effect of an atmosphere containing $3.8 \%$ carbon dioxide on the metabolism of unwashed ram spermatozoa ( 9 to $19 \times 10^{8}$ cells/flask) was investigated. The results for four ejaculates (Table 5) showed a significant fall in oxygen uptake in the presence of carbon dioxide but no significant change in the other parameters measured.

When a semen suspension in basic diluent, as used in the last experiment, was equilibrated with an atmosphere containing $3.8 \%$ carbon dioxide, the $\mathrm{pH}$ of the diluent fell by 0.3 units to $\mathrm{pH} 6 \cdot 7$. Thus change in $\mathrm{pH}$, rather than carbon dioxide per se, may have been responsible for the effect on oxygen

TABLE 3

EFFECT OF RESPIRED $\mathrm{CO}_{2}$ ON THE METABOLISM OF UNWASHED BULL SPERMATOZOA IN THE PRESENCE AND IN THE ABSENCE OF PHOSPHATE BUFFER

\begin{tabular}{c|c|c|c|c|c|c|c}
\hline \multirow{2}{*}{ Phosphate } & $\begin{array}{c}\text { Gas } \\
\text { phase }\end{array}$ & $\begin{array}{c}\mathrm{O}_{2} \\
\text { uptake }\end{array}$ & $\begin{array}{c}\text { Fructose } \\
\text { oxidized }\end{array}$ & $\begin{array}{c}\text { Lactate } \\
\text { oxidized }\end{array}$ & $\begin{array}{c}\text { Fructose } \\
\text { utilized }\end{array}$ & $\begin{array}{c}\text { Lactate } \\
\text { accumulated }\end{array}$ & R.Q. \\
\hline \multirow{2}{*}{-} & $-\mathrm{CO}_{2}$ & 1.42 & 0.045 & 0.278 & 1.24 & 1.45 & - \\
+ & $+\mathrm{CO}_{2}$ & 1.39 & 0.051 & 0.264 & 1.50 & 1.78 & 0.97 \\
& $-\mathrm{CO}_{2}$ & 1.35 & 0.047 & 0.206 & 1.79 & 2.38 & - \\
& $+\mathrm{CO}_{2}$ & 1.50 & 0.048 & 0.258 & 1.69 & 2.93 & 0.83 \\
\hline
\end{tabular}

All values are expressed as $\mu$ mole $/ 10^{8}$ spermatozoa over the experimental period ( $3 \mathrm{hr}$ ) and are the means for three ejaculates.

SUMMARY OF THE ANALYSES OF VARIANCE

\begin{tabular}{|c|c|c|c|c|c|c|c|}
\hline \multirow{2}{*}{$\begin{array}{l}\text { Source of } \\
\text { variation }\end{array}$} & \multirow[b]{2}{*}{$d . f}$. & \multicolumn{6}{|c|}{ Variance ratios } \\
\hline & & $\begin{array}{c}\mathrm{O}_{2} \\
\text { uptake }\end{array}$ & $\begin{array}{l}\text { Fructose } \\
\text { oxidized }\end{array}$ & $\begin{array}{l}\text { Lactate } \\
\text { oxidized }\end{array}$ & $\begin{array}{l}\text { Fructose } \\
\text { utilized }\end{array}$ & $\begin{array}{c}\text { Lactate } \\
\text { accumulated }\end{array}$ & $R . Q$. \\
\hline $\begin{array}{l}\text { A. Effect of phosphate } \\
\text { B. Effect of } \mathrm{CO}_{2}\end{array}$ & $\begin{array}{l}1 \\
1\end{array}$ & $\begin{array}{l}0.02 \\
0 \cdot 16\end{array}$ & $\begin{array}{l}0 \cdot 03 \\
0 \cdot 48\end{array}$ & $\begin{array}{l}1 \cdot 58 \\
0 \cdot 38\end{array}$ & $\begin{array}{l}3 \cdot 30 \\
0 \cdot 15\end{array}$ & $\begin{array}{c}35 \cdot 57 * * \\
6.82^{*}\end{array}$ & $\begin{array}{l}7 \cdot 61^{*} \\
-\end{array}$ \\
\hline $\mathbf{A} \times \mathbf{B}$ & 1 & 0.38 & $0 \cdot 22$ & 1.04 & $0 \cdot 74$ & 0.43 & - \\
\hline $\begin{array}{l}\text { Ejaculate differences } \\
\text { Ejaculate interactions }\end{array}$ & $\begin{array}{l}2 \\
6\end{array}$ & $\begin{array}{l}2 \cdot 84 \\
0.1141\end{array}$ & $\begin{array}{r}23.41 * * \\
0.0063\end{array}$ & $\begin{array}{l}3.07 \\
0.0029\end{array}$ & $\begin{array}{l}8.45^{*} \\
0.22\end{array}$ & $\begin{array}{l}3.23 \\
1.36\end{array}$ & (2) $\begin{array}{l}1.57 \\
0.0077\end{array}$ \\
\hline Within group variance & 12 & 0.0158 & - & - & 0.2474 & 0.1732 & (6) 0.0006 \\
\hline
\end{tabular}

* $P<0.05 ; * * P<0.01$.

uptake observed above. To test the effects of $3.8 \%$ carbon dioxide and $\mathrm{pH}$ separately, two incubation diluents of similar composition to that above were made using $\mathrm{pH} 7.3$ and 7.0 phosphate buffers. Aliquots of four ram ejaculates were incubated in the presence of $3.8 \%$ carbon dioxide in the diluent of $\mathrm{pH} 7 \cdot 3$ and compared with aliquots incubated in the absence of carbon dioxide in both the $\mathrm{pH} 7.0$ and 7.3 diluents. The $\mathrm{pH}$ of the gassed suspensions fell to 7.0 prior to incubation and comparison with the $\mathrm{pH} 7.0$ diluent tested the effect of $3.8 \%$ carbon dioxide, while comparison of the two incubations in the absence of carbon dioxide gauged the effect of $\mathrm{pH}$. The results (Table 6) showed a significant fall in fructose and lactate oxidized due to a lowered $\mathrm{pH}$. The presence of $3.8 \% \mathrm{CO}_{2}$ at a constant $\mathrm{pH}$ (i.e. $\mathrm{B} v . \mathrm{C}$ ) caused a significant increase in lactate accumulation but no other significant change. 
TABLE 4

EFFECT OF RESPIRED $\mathrm{CO}_{2}$ ON THE METABOLISM OF WASHED RAM SPERMATOZOA INGUBATED AT TWO SPERMATOZOAL DILUTIONS, WTTH FRUGTOSE AS SUBSTRATE AND IN THE PRESENCE AND ABSENCE OF $\mathrm{K}^{+}(1 \mathrm{mM})$ AND $\mathrm{Mg}^{2+}(2 \mathrm{~mm})$

\begin{tabular}{|c|c|c|c|c|c|c|}
\hline $\begin{array}{c}\text { Cell } \\
\text { concentration }\end{array}$ & $K^{+}+M g^{2+}$ & $\begin{array}{c}\text { Gas } \\
\text { phase }\end{array}$ & $\begin{array}{c}\mathrm{O}_{2} \\
\text { uptake }\end{array}$ & $\begin{array}{l}\text { Fructose } \\
\text { oxidized }\end{array}$ & $\begin{array}{l}\text { Fructose } \\
\text { utilized }\end{array}$ & $\begin{array}{c}\text { Lactate } \\
\text { accumulated }\end{array}$ \\
\hline \multirow[t]{2}{*}{ High } & - & $\begin{array}{l}-\mathrm{CO}_{2} \\
+\mathrm{CO}_{2}\end{array}$ & $\begin{array}{l}1.81 \\
1.82\end{array}$ & $\begin{array}{l}0.236 \\
0.219\end{array}$ & $\begin{array}{l}0.91 \\
0.85\end{array}$ & $\begin{array}{l}1.08 \\
1.07\end{array}$ \\
\hline & + & $\begin{array}{l}-\mathrm{CO}_{2} \\
+\mathrm{CO}_{2}\end{array}$ & $\begin{array}{l}2 \cdot 62 \\
2 \cdot 80\end{array}$ & $\begin{array}{l}0.382 \\
0.368\end{array}$ & $\begin{array}{l}1.66 \\
1.56\end{array}$ & $\begin{array}{l}2 \cdot 04 \\
2 \cdot 52\end{array}$ \\
\hline \multirow[t]{2}{*}{ Low } & - & $\begin{array}{l}-\mathrm{CO}_{2} \\
+\mathrm{CO}_{2}\end{array}$ & $\begin{array}{l}1.25 \\
1.40\end{array}$ & $\begin{array}{l}0.151 \\
0.167\end{array}$ & $\begin{array}{l}0.80 \\
0.43\end{array}$ & $\begin{array}{l}0.67 \\
0.87\end{array}$ \\
\hline & + & $\begin{array}{l}-\mathrm{CO}_{2} \\
+\mathrm{CO}_{2}\end{array}$ & $\begin{array}{l}2 \cdot 24 \\
2 \cdot 78\end{array}$ & $\begin{array}{l}0.345 \\
0.382\end{array}$ & $\begin{array}{l}1.56 \\
1.94\end{array}$ & $\begin{array}{l}2 \cdot 20 \\
2 \cdot 38\end{array}$ \\
\hline
\end{tabular}

Values are the means for four ejaculates and are expressed as $\mu$ mole $/ 10^{8}$ spermatozoa over the experimental period $(3 \mathrm{hr})$.

SUMMARY OF THE ANALYSES OF VARIANGE

\begin{tabular}{|c|c|c|c|c|c|}
\hline \multirow[b]{2}{*}{ Source of variation } & \multirow[b]{2}{*}{$d . f}$. & \multicolumn{4}{|c|}{ Variance ratios } \\
\hline & & $\begin{array}{c}\mathrm{O}_{2} \\
\text { uptake }\end{array}$ & $\begin{array}{l}\text { Fructose } \\
\text { oxidized }\end{array}$ & $\begin{array}{l}\text { Fructose } \\
\text { utilized }\end{array}$ & $\begin{array}{c}\text { Lactate } \\
\text { accumulated }\end{array}$ \\
\hline $\begin{array}{l}\text { A. Effect of potassium and magnesium } \\
\text { B. Effect of } \mathrm{CO}_{2} \\
\text { C. Effect of dilution }\end{array}$ & $\begin{array}{l}1 \\
1 \\
1\end{array}$ & $\begin{array}{l}58 \cdot 27^{* *} \\
2 \cdot 50 \\
6 \cdot 14^{*}\end{array}$ & $\begin{array}{l}61 \cdot 92^{* *} \\
0 \cdot 06 \\
3 \cdot 23\end{array}$ & $\begin{array}{l}45 \cdot 52^{* *} \\
0 \cdot 07 \\
0 \cdot 20\end{array}$ & $\begin{array}{l}78 \cdot 14^{* *} \\
1 \cdot 82 \\
0.94\end{array}$ \\
\hline $\begin{array}{l}\text { Interactions } \\
\quad \mathbf{A} \times \mathbf{B} \\
\mathbf{A} \times \mathbf{C} \\
\mathbf{B} \times \mathbf{C} \\
\mathbf{A} \times \mathbf{B} \times \mathbf{C}\end{array}$ & $\begin{array}{l}1 \\
1 \\
1 \\
1\end{array}$ & $\begin{array}{l}1.02 \\
1.08 \\
0 \cdot 88 \\
0 \cdot 15\end{array}$ & $\begin{array}{l}0.07 \\
1.64 \\
0.90 \\
0.04\end{array}$ & $\begin{array}{l}1 \cdot 59 \\
2 \cdot 09 \\
0 \cdot 11 \\
1 \cdot 98\end{array}$ & $\begin{array}{l}0.57 \\
1.07 \\
0.02 \\
0.65\end{array}$ \\
\hline $\begin{array}{l}\text { Ejaculate differences } \\
\text { Ejaculate interactions (error) }\end{array}$ & $21^{3}$ & $\begin{array}{c}54 \cdot 45 * * \\
0.149\end{array}$ & $\begin{array}{c}26.03 * * \\
0.004\end{array}$ & $\begin{array}{l}8 \cdot 87^{*} \\
0 \cdot 154\end{array}$ & $\begin{array}{l}9 \cdot 26^{*} \\
0.189\end{array}$ \\
\hline
\end{tabular}

* $P<0.05$;** $P<0.01$.

TABLE 5

EFFECT OF $3 \cdot 8 \% \mathrm{CO}_{2}$ ON THE METABOLISM OF UNWASHED RAM SPERMATOZOA.

\begin{tabular}{l|l|l|l|l|l|c}
\hline $\begin{array}{c}\text { Gas } \\
\text { phase }\end{array}$ & $\begin{array}{l}\text { Oxygen } \\
\text { uptake }\end{array}$ & $\begin{array}{l}\text { Fructose } \\
\text { oxidized }\end{array}$ & $\begin{array}{l}\text { Lactate } \\
\text { oxidized }\end{array}$ & $\begin{array}{l}\text { Fructose } \\
\text { utilized }\end{array}$ & $\begin{array}{c}\text { Lactate } \\
\text { accumulated }\end{array}$ & R.Q. \\
\cline { 2 - 6 }$-\mathrm{CO}_{2}$ & 2.04 & 0.117 & 0.391 & 1.52 & 1.92 & - \\
$+\mathrm{CO}_{2}$ & $1.81^{*}$ & 0.126 & 0.412 & 1.45 & 1.96 & 1.04 \\
S.E.m & $0.06(8)$ & $0.004(3)$ & $0.014(3)$ & $0.03(8)$ & $0.10(8)$ & $0.02(4)$ \\
\hline
\end{tabular}

All values are expressed as $\mu$ mole $/ 10^{8}$ spermatozoa over the experimental period $\left(1 \frac{1}{2}\right.$ to $2 \mathrm{hr}$ ) and are the means for four ejaculates.

* Significant effect of $\mathrm{CO}_{2} ; P<0 \cdot 05$. 
To investigate the effect of oxygen tension on the metabolism of ram spermatozoa, aliquots of ram semen ( 4.5 to $6.0 \times 10^{8}$ cells/flask) were incubated after flushing the flasks with either air or $100 \%$ oxygen. The results are summarized in Table 7 . With the increase in oxygen tension there was a small but significant increase in fructose utilization and a decrease in the amount of lactate oxidized. Total oxygen uptake and fructose oxidation were unaffected by the change in oxygen tension.

TABLE 6

EFFECT OF $3.8 \% \mathrm{CO}_{2}$ AND OF $\mathrm{pH} 7.0$ AND $\mathrm{pH} 7.3$ ON THE METABOLISM OF UNWASHED RAM SPERMATOZOA

\begin{tabular}{|c|c|c|c|c|c|c|}
\hline Treatment & $\begin{array}{c}\text { Gas } \\
\text { phase }\end{array}$ & $\begin{array}{c}\mathrm{O}_{2} \\
\text { uptake }\end{array}$ & $\begin{array}{l}\text { Fructose } \\
\text { oxidized }\end{array}$ & $\begin{array}{c}\text { Lactate } \\
\text { oxidized }\end{array}$ & $\begin{array}{l}\text { Fructose } \\
\text { utilized }\end{array}$ & $\begin{array}{c}\text { Lactate } \\
\text { accumulated }\end{array}$ \\
\hline $\begin{array}{l}\text { A. Diluent pH } 7 \cdot 3 \\
\text { B. Diluent pH } 7 \cdot 3 \\
\text { C. Diluent pH } 7 \cdot 0 \\
\text { S.E.m }\end{array}$ & $\begin{array}{l}-\mathrm{CO}_{2} \\
+\mathrm{CO}_{2} \\
-\mathrm{CO}_{2}\end{array}$ & $\begin{array}{l}1.97 \\
2.07 \\
1.76 \\
0.12(6)\end{array}$ & $\begin{array}{l}0 \cdot 052 \\
0 \cdot 046^{* *} \\
0 \cdot 045^{* *} \\
0.004(6)\end{array}$ & $\begin{array}{l}0.420 \\
0.388 \\
0.362 \\
0.006(6)\end{array}$ & $\begin{array}{l}1.49 \\
1 \cdot 66 \\
1.35 \\
0.17(6)\end{array}$ & $\begin{array}{l}2 \cdot 44 \\
2 \cdot 69 \\
2 \cdot 17 \dagger \\
0 \cdot 14(12)\end{array}$ \\
\hline
\end{tabular}

All values are expressed as $\mu$ mole $/ 10^{8}$ spermatozoa over the experimental period $(2 \mathrm{hr})$ and are the means for four ejaculates.

** Significantly different from A, $P<0.01$.

$\dagger$ Significantly different from $B, P<0.05$.

TABLE 7

METABOLISM OF UNWASHED RAM SPERMATOZOA IN THE PRESENCE OF AIR AND $100 \%$ OXYGEN

\begin{tabular}{l|l|l|l|l|l}
\hline Gas phase & $\begin{array}{l}\text { Oxygen } \\
\text { uptake }\end{array}$ & $\begin{array}{c}\text { Fructose } \\
\text { oxidized }\end{array}$ & $\begin{array}{l}\text { Lactate } \\
\text { oxidized }\end{array}$ & $\begin{array}{l}\text { Fructose } \\
\text { utilized }\end{array}$ & $\begin{array}{l}\text { Lactate } \\
\text { accumulated }\end{array}$ \\
\cline { 2 - 5 } Air & 1.29 & 0.096 & 0.315 & 1.41 & 1.98 \\
Oxygen & 1.32 & 0.100 & $0.281^{*}$ & $1.52^{*}$ & 2.37 \\
S.E.m & $0.07(2)$ & $0.012(2)$ & $0.004(2)$ & $0.02(5 \dagger)$ & $0.26(5 \dagger)$ \\
\hline
\end{tabular}

Values are expressed as $\mu$ mole $/ 10^{8}$ spermatozoa over the $2 \mathrm{hr}$ experimental period and are the means for three ejaculates.

* Significant difference between treatments, $P<0.05$.

$\dagger$ d.f. reduced by 1 to correct for missing value.

\section{DISCUSSION}

There are relatively few references in the literature to the effects of carbon dioxide on ram spermatozoa. Humphrey \& Mann (1949) reported that a $35 \%$ increase in oxygen uptake of washed ram spermatozoa occurred in the presence of $5 \%$ carbon dioxide. On the other hand Scott, White \& Annison (1962) found no increase in the metabolism of propionate by washed ram spermatozoa suspended in calcium-free Krebs'-Ringer bicarbonate and incubated in an atmosphere of $95 \% \mathrm{O}_{2}: 5 \% \mathrm{CO}_{2}$. The results presented in the present paper support the latter report.

It is difficult to explain these conflicting reports on the effects of carbon 
dioxide on the metabolism of ram spermatozoa. It does not seem that changes in experimental conditions have any marked effect on the reaction of spermatozoa to the presence of carbon dioxide. Thus in the present study, washing the spermatozoa free of seminal plasma, changing the cell concentration in the incubation flasks or adding phosphate, potassium and magnesium to the suspensions did not produce any difference in metabolism between spermatozoa incubated in the presence or in the absence of respired carbon dioxide. From the study of the effects of $3.8 \%$ carbon dioxide in the present experiments, however, it is obvious that $\mathrm{pH}$ changes resulting from the addition of carbon dioxide must be considered in any assessment of the effects of this gas. In the case of respired carbon dioxide, $\mathrm{pH}$ effects due to accumulated carbon dioxide must be relatively unimportant since there were no differences in metabolism during incubations in unbuffered isotonic saline or in phosphate buffer, and there was no interaction of carbon dioxide and the presence of buffer.

Washing ram spermatozoa increased oxygen uptake and decreased glycolysis. There was also a small but significant increase in respiratory quotient after washing which may indicate the removal of a small amount of noncarbohydrate substrate during washing. The significant increase seen in lactate oxidation after washing may be an artifact and only reflect an increase in the initial entry of lactate into the tricarboxylic acid cycle. Experiments in this laboratory (T. O'Shea \& R. G. Wales, unpublished data) indicate that the use of $1-{ }^{14} \mathrm{C}$ lactate in washed suspensions gives an over-estimation of the oxidation of lactate.

The results presented here for bull spermatozoa do not confirm the earlier reports that respired carbon dioxide stimulates the respiration of unwashed bull spermatozoa (Salisbury \& Lodge, 1963; Lodge \& Salisbury, 1963). There was, however, a small increase in lactate accumulated in the presence of carbon dioxide. The origin of this added lactate is obscure as there was no corresponding change in fructose utilization as would be expected if there had been an increase in glycolysis. A similar increase in lactate accumulation without changes in fructose utilization was noted when ram spermatozoa were incubated in the presence of $3.8 \%$ carbon dioxide.

In these experiments, the respiratory quotients found for ram spermatozoa with and without added substrate ( 1.0 and 0.78 respectively) are in close agreement with those reported by Ivanov (1936). Hartree \& Mann (1959) found a respiratory quotient of 0.71 for washed ram spermatozoa after first allowing metabolism to proceed for $2 \mathrm{hr}$ to remove any remaining exogenous substrates and used this value as indirect evidence for lipid metabolism. The slightly higher respiratory quotients found in the present experiments may indicate that there was a small amount of absorbed or residual carbohydrate in the washed suspensions which was not detected by the available analytical procedures.

The respiratory quotient of 1.0 obtained for ram spermatozoa incubated in the presence of fructose and lactate indicates that lipids do not enter into the metabolism of the cell in normal circumstances where exogenous substrates are present. The results obtained using labelled isotopes confirm this suggestion as all the oxygen uptake of unwashed and washed suspensions was due to the 
oxidation of fructose and lactate. Wallace \& Wales (1964) indicated that the oxygen uptake not accounted for by fructose oxidation in unwashed suspensions of ram spermatozoa was due to the presence of a dialysable seminal constituent rather than due to endogenous respiration.

In the various experiments with ram spermatozoa incubated in the presence of fructose, the respiratory quotient was approximately unity, whether the period of incubation was $1 \frac{1}{2}$ or $3 \mathrm{hr}$. This suggests that during a 3-hr incubation the respiratory quotient stays constant at near unity. This is consistent with the observation that fructose and lactate oxidation account for the major part of the oxygen uptake over that time. It does not, however, support the observation of Humphrey \& Mann (1949) that in the presence of fructose there was a fall in respiratory quotient over $3 \mathrm{hr}$ from 1.0 to 0.79 .

The results confirm the report of Humphrey \& Mann (1949) that variations in the partial pressure of oxygen have no effect on the respiration of ram spermatozoa. The significant decrease in lactate oxidized in the presence of $100 \%$ oxygen was presumably due to the increase in fructose utilized. Fructose plus lactate oxidized (i.e. total exogenous substrate oxidized) showed no significant effect of oxygen tension.

\section{ACKNOWLEDGMENTS}

The authors are indebted to Professor C. W. Emmens for interest and criticism. This work was aided by grants from the Rural Credits Development Fund of the Commonwealth Bank of Australia and the Australian Wool Board. One of us (T.O'S.) was supported by a Walter and Eliza Hall Research Fellowship.

\section{REFERENCES}

BLACKshaw, A. W. (1954) A bipolar rectal electrode for the electrical production of ejaculation in sheep. Aust. vet. F. 30, 249.

Hartree, E. F. \& ManN, T. (1959) Plasmalogen in ram semen, and its role in sperm metabolism. Biochem. F. 71, 423.

Humphrey, G. F. \& ManN, T. (1949) Studies on the metabolism of semen. 5. Citric acid in semen. Biochem. J. 44, 97.

Ivanov, I. I. (1936) Biochemistry (U.S.S.R.), 1, 245. Quoted by Salisbury, G. W. \& Lodge, J. R. (1962) Metabolism of spermatozoa. Adv. Enzymol. 24, 35.

Lodge, J. R. \& SAlisbURY, G. W. (1963) Factors influencing metabolic activity of bull spermatozoa. VI. Metabolic $\mathrm{CO}_{2}$ and fructose. F. Dairy Sci. 46, 140.

O'Shea, T. \& Wales, R. G. (1965). Metabolism of sorbitol and fructose by ram spermatozoa. $\mathcal{J}$. Reprod. Fert. 10, 353.

Salisbury, G. W. \& KinNey, W. C. (1957) Factors influencing metabolic activity of bull spermatozoa. III. pH. 7. Dairy Sci. 40, 1343.

SAlisbury, G. W. \& Lodge, J. R. (1963) Respiratory quotients of bovine spermatozoa. 7. Reprod. Fert. 5, 195.

Salisbury, G. W. \& VanDemark, N. L. (1957) Carbon dioxide as a reversible inhibitor of spermatozoan metabolism. Nature, Lond. 180, 989.

Scott, T. W., White, I. G. \& ANnison, E. F. (1962) Oxidation of short-chain fatty acids $\left(\mathrm{C}_{\mathbf{1}}-\mathrm{C}_{\mathbf{8}}\right)$ by ram, bull, dog and fowl spermatozoa. Biochem. $\mathbf{7 . ~ 8 3 , 3 9 2 . ~}$

Wallace, J. \& Wales, R. G. (1964) Effect of ions on the metabolism of ejaculated and epididymal ram spermatozoa. 7. Reprod. Fert. 8, 187. 